\title{
The Evolution of the Integration Process as Effect of the Treaties Signing Between the Republic of Moldova and European Union
}

\author{
Mămăligă Ilie \\ Associate Professor, Doctor of Law, Institute of \\ Legal and Political Researches of Academy of Sciences of Moldova \\ Address: Stefan cel Mare avenue 1, MD-2001, Chisinau, Republic of \\ Moldova, \\ E-mail: iliemamaliga@gmail.com
}

\begin{abstract}
The aim of this paper is to investigate the evolutive aspect of the political, economic and commercial development of the Republic of Moldova's relations with the European Union and the de jure and de facto adhesion to this European Forum. Thus, it argues and testifies that after 2024 the Republic of Moldova will become a titular member of the European Union, also, it counts those 4 evolutive stages of the development of this process.
\end{abstract}

In this way, it is specified the 3rd evolutive stage (2014-2020/24), particularly 2014, of the European integration process of the Republic of Moldova in comparison with Romania and Bulgaria in 2001. It is demonstrated that the European integration of the Republic of Moldova represents a perpetual process, which depends on and coincides with the process of the transnistrian conflict solving, and the signing the Republic of Moldova - EU Association Agreement and Deep and Comprehensive Free Trade Agreement represents the effect of advancing to a new evolutive phase. These agreements substantiate on vertical and horizontal dimension of the economic relations with the European Union.

So, it is noticed that the success of this progress represents the new agreements with favorable clauses for the Republic of Moldova in comparison with the previous ones, stipulated in the Partnership and Cooperation Agreement. As a consequence, it appears the passage to new phase of relation development with EU in comparison with the Partnership and Cooperation Agreement signed in 1994.

Consequently, in a different hypothesis, it is put forward the idea of the accelerated advancement of the adhesion process of the Republic of Moldova to the European Union after 2020, provided the resolution of the transnistrian conflict till that period, the gain of new market places of national products, the independent development of an economy based on renewable energy resources, such as eolian and solar energy etc.

The liberalization of viza regime in 2014 represents the sine qua non condition of the intensification of the republic of Moldova relations within new geopolitical circumstances and creates real conditions for the acceleration of this economic integration process.

Key-words: European integration process, European treaties, Association Agreement Association Agreement the Republic of Moldova-European Union, Deep and Comprehensive Free Trade Agreement, new geopolitical circumstances 


\section{European integration - the primary stage of the Republic of Moldova (1989- 1994)}

The phrase "European integration" and the development stages of this process represent a relevant significance for the Republic of Moldova, depending on certain events, such as the signing of some treaties in certain geopolitical circumstances, the proximity with the European Union, the abolishment of vizas for citizens of the Republic of Moldova etc. Such events can serve as evidence of enlargement of the European integration process, from the Western Europe to Eastern Europe.

A major achievement of the European integration process of the Republic of Moldova was the signing of the Association Agreement with the European Union on 27 June 2014. This treaty serves as a solid legal basis for the creation of a unique policy in all areas of social life of the Member States of EU and the associated members.

Thus, we distinguish four (4) phases of European integration process for the Republic of Moldova, strengthening the European vector, promoted at the concept of internal and foreign policy of the state.

So, the first stage covers the period of 1989-1994 years, externally, it is directly linked to the Agreement between the European Atomic Energy Community and the Union of Soviet Socialist Republics on the trade and commercial-economic cooperation, signed on 18 December 1989. The internal aspect is related to the events concerning the national liberation movement by Statements on the proclamation of sovereignty and independence of the Republic of Moldova, of the Laws on the Latin script, anthem, flag etc., including the adopting of the Constitution of the Republic of Moldova.

The Preamble of the nominated Economic treaty follows that the European Economic Union wanted to "encourage the process of regional cooperation with neighboring republics to favoring a gradual rapprochement between the former Soviet Socialist Republic and a wider area of cooperation in Europe and neighboring regions, and the gradual integration of the Moldavian Soviet Socialist Republic within the opened international trading system".

Further, the provision of the 3rd Article of the Agreement provides: "for the future prosperity and stability of the region of the former Soviet Union, it is essential that the new independent states emerged from the dissolution of the USSR, maintain and develop cooperation between them". The sides said that they would undertake all necessary efforts to encourage this process.

In the opinion of V. Pohniţchi “... by signing of the Agreement it was wanted to create a better climate for economic relations between the sides, emphasizing the priority of the trade and investments, which are essential to economic restructuring and technological upgrading. One of the important provisions of the agreement is the acceptance of the principle of free and unrestricted transit of goods from the customs territory of one of the sides or for the customs territory of the other side. The exported goods should be to be sold at market prices, being prohibited the certain direct or indirect imposition and internal taxes, beyond those applied to the similar autochthone goods. In addition, the exported products by one of the sides to the other side shall be accorded the treatment no less favorable than that accorded to the products of national origin in accordance with local law." [1]

Typically for the 1st phase of 1989-1994 years, it is that the commercial-economic Agreement from 1989 is based on market economy principles and the principles of international law, while in the ex-Soviet republics dominate the administrative control principles, characteristic of the socialist system. Even the Preamble to the Treaty stipulates the encouraging of regional cooperation process and an 
approaching and gradual integration of the former Moldavian SSR (nowadays the Republic of Moldova) in the context of cooperation, and other former Soviet republics bordering the countries of Western Europe and their inclusion in the opened international trading system.

\section{The Partnership and Cooperation Agreement - an instrument of the relations' development between the Republic of Moldova and the European Union (1994-2011/14)}

A second stage of the evolution of relations between the Republic of Moldova and the European Union (1994-2014) is indispensable for the fact that the Partnership and Cooperation Agreement (PCA) was signed between the two sides. PCA, on 1994-2014 years, represents the most relevant legal framework between the Republic of Moldova and the EU, although the signing of other bilateral and multilateral economic treaties, strengthened this perpetual process.

The RCA was signed on 24th November 1994 and entered into force on 1st July 1998 for a period of 10 years with the possibility of extending its application until to the signing of a Deep and Comprehensive Association Agreement, ie until 27th June 2014.

This stage is manifested by the fact that PCA embodies all sectors of social life, including the public institutions with the EU, including the political, commercial, economic, legal, cultural, scientific, transportation, industrial, medical, agricultural etc. This treaty are based on several objectives: the strengthening of democracy, the rule of law, the protection of human rights and fundamental freedoms, including minorities.

The sustainable development of economy and the further deepening of relations and the respect of the principles of the market economy through trade etc.. The relations between the Republic of Moldova and the EU were institutionalized basing on 4 structures to develop the political dialogue and supervision of public authorities at central level: 1) Cooperation Council; 2) Cooperation Committee (of the government level); 3) The Parliamentary Cooperation Committee and 4) Cooperation Subcommittees.

The signing of the EU-the Republic of Moldova Action Plan in 2005, which contains the strategic objectives and actions that will strengthen the of the legal system of Republic of Moldova harmonization process to the Community Acquis standards continue until the achievement of these objectives [2].

During this period, the Republic of Moldova's European integration policy is based on 2 pillars, as the implementation of the EU-the Republic of Moldova Action Plan and realizing of the possibilities of the Republic of Moldova to participate in all regional initiatives.

According to I. Clipii, "a major and longterm objective of the foreign policy of the Republic of Moldova is a gradual integration into the European Union. The first step in this pathway is the signing of the Partnership and Cooperation Agreement" [3].

Therefore, we consider that the PCA is already the second stage or the second relevant step in the process of European integration of the Republic of Moldova, being preceded, on external aspect, by the Economic Agreement signed in 1989, and on domestic plan - by stock of laws on sovereignty and independence, including the state symbols, stipulated in the Fundamental Law and other organic laws.

The scientific aspect of this phase (II) is characterized by the signing of the Memorandum of FP7 (Framework Programme 7) on 27th October 2011 relating to the research and information technology and signed by the President of ASM, Gheorghe Duca, and Commissioner for Research, Innovation and Science, Maire Geoghegan - Quinn, in force and implemented from January 1st, 2012. 
Fallowing to signing the Memorandum of Understanding between the European Union and the Republic of Moldova on the association of the Republic of Moldova to the 7th Framework Programme of the European Community for research, technological development and demonstration activities (2007-2013), from October 2011, (CIP) Center of International projects of Academy of Sciences of Moldova was officially nominated by ASM to contribute to the implementation of the status of associated country [4].

Similarly, the Common Aviation Area Agreement the Republic of Moldova European Union [5], signed on 26th June 2012 at the meeting of the EU - the Republic of Moldova Cooperation Council, entered into force provisionally by diplomatic verbal notes exchange, according to the 29th article of the Treaty and ratified by the Parliament of the Republic of Moldova. A provisional entry into force of the mentioned agreement offered to the airlines companies from the European Union the possibility to work in the Republic of Moldova and to Moldovan companies - on territory of the Member States of the European Union. Therefore, the liberalization of air services in the EU has favored the attraction of other European companies to Moldova, including those of low cost type, that has led to lowering of the ticket prices, the number of routes and destinations, the providing of the adequate services etc.. In this respect, the Moldovan authorities have initiated a series of active measures to modernize and other airports from country, as Mărculeşti, Bălți and Cahul.

The Government Agenda "European Integration: Freedom, Democracy, Welfare" provides the governing policy framework of the Republic of Moldova for 2011-2014 years and represents an integral part of this stage.

"This program is an expression of continuity in meeting commitments to the citizens, and our external partners. The strategic vision of the proposed program is to increase welfare, which will focus on two major objectives of Government: the raising of living standards and the European integration. The achievement of these broad objectives will undertake a number of actions for the social protection of citizens, the economic development, the strengthening of the rule of law state, the increase of employment, the development of relationships with external partners, the investment attracting, the abolishment of viza and other acts, which set as an intention the better life for our citizens. [6]" Further, the program refers to "Activity Program of the Government, as a whole, aims to create a high level of welfare of the Moldovan citizens, and achieve other important changes in society that, in their entirety, would accelerate the integration of the Republic of Moldova into European Union". [7]

We consider that this program has been partially fulfilled, because it was not achieved those strategic objectives for the economic development, the social protection of citizens, the foreign investments etc..

On 4th March 2014, the President of European Parliament, Martin Schulz, and EU Council representative, Deputy Foreign Minister of Greece, Dimitris Kourkoulas, had signed the Amendment of the 539/2001 Regulation to allow the transfer of the Republic of Moldova in the list of third countries whose nationals are exempt from a viza.

The decision of liberalization of the viza regime for Moldovan citizens is stipulated in the Regulation nr.259/2014 of the European Parliament and of the Council of 3rd April 2014 amending the Regulation (EC) nr.539/2001 of the Council that establish the list of third countries whose nationals must be in possession of vizas when crossing the external borders and the list of countries whose nationals are exempt 
from that requirement, published in the Official Journal of the European Union L 105, p. 9-11.

The practical experience demonstrates an increased attraction to residents of the left bank of Nistru for the biometric passports and citizenship of the Republic of Moldova. Even some citizens of former Soviet republics, including Russia's eastern districts require a residence in order to obtain citizenship of Moldova and biometric passport to travel later in the EU without a viza.

The liberalization of the viza regime since April 28, 2014 is an attraction of Moldovan citizens to the EU member states, but also a bridge between the two sides of Nistru, by attracting the residents from the eastern districts of the Republic of Moldova to unify the country.

\section{The Association Agreement - a new} dynamic stage of the process of European integration (2014-2020/24). The 3rd stage

The distinctive point of the 3rd stage is the fact that it starts with the signing of the Association Agreement at Brussel on 27th June, 2014, and continues on 2nd July with the ratification of the Agreement by Parliament, and until November 2014 the Parliaments of 28 Member States of EU should ratify the Treaty. Such procedures for ratification of the Association Agreement allows the Republic of Moldova to implement its terms immediately.

Thus, the 1st Article of the Agreement establishes an association between the European Union and its Member States with the Republic of Moldova having the following purposes:

a) to promote the political association and economic integration between the sides on the basis of shared the common values and close relations, including the increased participation of the Republic of Moldova within the policies, programs and agencies of the European Union; b) to strengthen the political dialogue in all domains of mutual interest, which will contribute to the development of close political relations between the sides;

c) to contribute to the consolidation of the democracy and political, economic and institutional stability of the Republic of Moldova;

d) to promote, to preserve and to strengthen the peace and stability on the regional and international dimensions, including the joint efforts to eliminate the sources of tension, to increase the border security, to promote the cross-border cooperation and good neighborly relations;

e) to support and to strengthen the cooperation on the domains of justice, freedom and security in order to strengthen the rule of law state and the respect of human rights and fundamental freedoms, as well as in the area of mobility and contacts between people;

f) to support the Republic of Moldova's efforts to develop its economic potential through the international cooperation and harmonizing its legislation with the EU legislation;

g) to create the conditions for the trade and economic relations that will lead to the gradual integration of the Republic of Moldova into EU internal market, as stated in this Agreement, including the establishment of a Deep and Comprehensive Free Trade Area, which will provide an extensive harmonization of the regulatory framework and liberalization of market access, in accordance with the rights and obligations arising from membership of the WTO; and to the transparent application of these rights and obligations;

h) to create the conditions for closer cooperation in other areas of mutual interest. [8]

Currently, we are at the start of this particularly relevant stage, which practically decide the future of the Republic of Moldova with the European Union. This means that the Republic of 
Moldova goes to another area of influence, than CIS, on political, economic, social, cultural and scientific aspect. "The European Union exerts a powerful force of attraction especially by "the people's everyday level of lives". The teacher, doctor, chemist, pharmacist, engineer see in the European Union a true "golden city", where the revenues are 3000-7000 dollars per month" [9], the equivalent of 23005200 euros in 2005-2006. While in Romania the monthly salary income in 2014 reached the level of 400-2500 euro, in Bulgaria the concerned categories have a monthly gain of 350-2400 euros, while in Croatia the salary of categories of employees arrive at the amount of 4502800 euros. Concerning the Republic of Moldova at the aspect regarding the average wage of the same category of employees is 120-250 euros per month, excepting the worker, farmer, or retired in some cases, their income is lower.

So, we see that the benefits of these advances is limited to the fact that in recent treaties there are contained clauses more favorable to the Republic of Moldova comparing to the previous ones.

Therefore, Republic of Moldova will execute the clauses according the Associate Membership Agreement, i.e. to follow the path traveled by the Baltic States, Romania, Bulgaria, taking into account the specific geographical situation, the Transnistrean conflict and other circumstances, which influence the EU relations with the Republic of Moldova. [10]

On the 28th April 2014 took place the liberalization of the viza regime for citizens of the Republic of Moldova for the EU and candidate countries. Such event shall be equivalent to the 1st January 2001 for Romania and Bulgaria and from that event to the full membership it passed six years.

The National Action Plan for the implementation of the Deep and Comprehensive Association Agreement the Republic of Moldova - European Union for
2014-2016 [11] represents the basic document for the monitoring of the European integration process in the next 3 years.

Negotiations on the Association Agreement were completed on 25 June 2013, and the Agreement was initialed on 29 November 2013. Before the full Agreement enters into force, measures must be put in place to ensure that the parties are able to enjoy its full benefits; the Agreement's partial provisional application is the first of these measures. The aim of the Association Agenda is to prepare and facilitate the implementation of the Association Agreement, by creating a practical framework through which the overriding objectives of political association and economic integration can be achieved. It replaces the EU-Moldova European Neighbourhood Policy Action Plan. [12]

Therefore, in practical terms, the immediate implementation of the Association Agreement will continue by obtaining of the candidate status, and later - full membership's rights within the European Union.

So, the 4th stage starts with becoming a Member State of the European Union after 2020. European Union seeks to promote peace, its values and the welfare of its peoples. (Article 2, paragraph 1).

The European Union shall offer to its citizens an area of freedom, security and justice, without internal frontiers, where there is ensured the free movement of persons in conjunction with appropriate measures with respect to external border controls, the rights for asylum, immigration and the criminality prevention and combating of this phenomenon (article 2, paragraph 2 of the Treaty of Lisbon [13] ).

So, hypothetically, we launch the idea of joining the Republic of Moldova to the European Union after 2020, creating the best performing economic, social and security conditions, at the internal level, 
and using the geopolitical conjuncture, including the resolution of conflict from the eastern districts of the Republic of Moldova, the strengthening of the Association relations of Ukraine with the European Union etc

Refererences and Notes
1) Prohinițchi V. Evaluarea
posibilităților de aderare la Uniunea Europeană. In: Moldova și Integrarea Europeană. Chișinău: Editura Prut Internațional, 2001. p. 156

2) It means the Regional Cooperation Council (The Pact of the Stability of the Southeastern Europe), the Cooperation process in Southeastern Europe and modified CEFTA Agreement (The Southeastern Europe Agreement of Free Trade).

3) Igor Clipîi. Evoluția cadrului politic al problemei integrării europene. In: Moldova și Uniunea Europeană. Chișinău: Editura Prut Internațional, 2001. p. 10.

4) See The Memorandum of Understandng between the European Union and the Republic of Moldova on the association of the Republic of Moldova to the Seventh Framework Programme, October 2011, JO L 412, 30.12.2006, p.1.

5) All stipulations of the Agreement will be valuable concomitantly with temporary entering in force until the end of the all European Parliament ratifications procedures.

6) Programul de activitate al Guvernului „Integrarea Europeană: Libertate, Democrație, Bunăstare" pentru perioada 20112014, Chișinău,2011, p. 4, it was partially achieved.

7) Ibidem, Introducere a Programului de activitate al Guvernului 2011-2014, p. 4.
8)

Association Agreement between the European Union and the European Atomic Energy Community and their Member States, of the one part, and the Republic of Moldova, of the other part. p. 6 .

9) The incomes of 3000-7000 dolars are reported to 2005-2006years, but in 2014 the incomes are higher. See: Mazilu D. Integrare Europeană. București: Lumina Lex, 2006. p. 67.

10) Mămăligă I. Aspects of Impletation of European Law in the Legal System of the Republic of Moldova within European Integration Process In: ACTA UNIVERSITATIS DANUBIUS. ADMINISTRATIO, No 1/2011, p. 56, ISSN:2068-5 .

11) The Republic of Moldova - EU Association Agreement was initialed on 28th to 29th November 2013 in Vilnius, Lithuania and signed on 27th June 2014 in Brussels, Belgium, and on the 2nd July 2014 was ratified by the Parliament and ratified by the 28 EU Member States: Romania, Estonia, Latvia, Lithuania, Germany, France, Italy, Spain, Portugal, Belgium, Netherlands, Luxembourg, Denmark, United Kingdom and Northern Ireland, Finland, Sweden, Austria, Greece, Poland, Hungary, Bulgaria, Malta, Cyprus, Slovenia, Czech Republic, Slovakia, Ireland, Croatia.

12) Association Agenda between the European Union and the Republic of Moldova, Brussels, 26 June 2014, p. 1.

13) The Amendment of the Treaty on European Union and the Treaty establishing the European Community, called the Lisbon Treaty was adopted in Brussels on 3rd December 2007 and entered into force on 1st December 2009. 